\title{
Punishment and Welfare: Defending offender's inclusion as subjects of state care
}

This is an Accepted Manuscript of an article published by Taylor \& Francis in Ethics and Social Welfare on $17^{\text {th }}$ August 2017, available online:

https://www-tandfonline-com.libproxy.ucl.ac.uk/doi/full/10.1080/17496535.2017.1364398

Please cite the final published article (the Version of Record) available at the above link where possible.

Accepted for publication 2nd August 2017

Helen Brown Coverdale

Department of Government, London School of Economics

Abstract

Many criminal offenders come from disadvantaged backgrounds, which punishment entrenches. Criminal culpability explains some disadvantageous treatment in state-offender interactions; yet offenders remain people, and 'some mother's child', in Eva Kittay's terms. Offending behaviour neither erases needs, nor fully excuses our responsibility for offenders' needs. Caring is demanded in principle, recognising the offender's personhood. Supporting offenders may amplify welfare resources: equipping offenders to provide self-care; to 
meet caring responsibilities; and enabling offenders' contribution to shared social life, by providing support and furthering the choices of others seeking to engage with them. The desistance paradigm (viewing desistance from offending as a process, following from an offender's active choice in the context of stabilising social structures and personal circumstances), implies that a supportive environment may facilitate reduced recidivism. While decisions about criminal culpability need justice, we may use state resources most effectively by also including care ethics in our thinking about punishment.

Keywords: care ethics; equality; caring practice; criminal justice; criminal punishment; treatment as equals; desistance; welfare; Eva Kittay; personhood

Introduction Prison reform in England and Wales received a high profile in British Prime Minister David Cameron's final legislative plan in early 2016. This was surprising, since it is often difficult to find legislative time for the interests of people who have offended. Cameron asserted that prisons should be 'places of care, not just punishment' (2016). Although some potentially positive steps were proposed in the White Paper outlining the 
Government's plans (increasing prison staff numbers, prison officer training, and a focus on rehabilitation Ministry of Justice 2016), these were widely criticised as underresourced and inadequate (Sim 2016). After a period of uncertainty under Prime Minister May and Minister for Justice Truss, the proposed changes were ultimately scrapped. Problems of severe overcrowding, low morale among staff and violence in prisons in England and Wales persist. Given the legislative attention that Brexit demands, and May's unstable Premiership following the unexpected 2017 British General Election, the future of prison reform under Minister for Justice Lidington is unclear, as prison reform is absent from current legislative proposals.

People who have offended should, as Cameron argued, be valued; but not as 'potential assets to be harnessed' (Cameron 2016). This language is deeply troubling: offenders are not objects to be exploited as instruments of capitalist enterprise. Offenders are people with pasts, but also families and futures. Following the Kantian duty to recognise persons as ends in themselves, we should not value people who have offended only as mere instrumental means to societal benefits. Care and relational ethical approaches also suggest that all persons are entitled to care and support. We should support offenders as intrinsically valuable persons. Further, if we can derive the greatest amount of benefit per unit of resource by targeting assistance to the least well-off members of society, and if many offenders are among these least 
well-off people, then pragmatically, caring for offenders has potential to amplify the effects of state welfare resources. Supporting offenders may be particularly helpful, if we can persuade individuals to move away from harmful behaviours, to themselves and others; and towards constructive social engagement. But the potential benefits to the offender's community, including the offenders' desistance, social contributions, and the amplification of welfare resources, are side-benefits, adding instrumental weight only to the case for supporting offenders.

This paper considers state obligations towards criminal offenders, arguing that caring is primarily demanded in criminal punishment, in recognition of offenders' equal personhood. Eva Feder Kittay's 'some mother's child' paradigm motivates empathy by grounding a shared basic dignity in the human experience of receiving care, and highlights indirect reciprocity through nested relationships. Care ethics more broadly stresses the significance of relationships (Barnes 2012, 145). While I do not discuss offenders' agency, nothing here should be taken to suggest that offenders should be passively infantilized as care is provided. Care providing requires an active, responsive engagement, and collaboration between care-giving and care-receiving parties. The at least partly mutually dependent process of caring-with is useful for understanding participatory relationships between individuals and state agents, detailed in Barnes and Prior (2009). Care ethics has been applied in similar apparently counter intuitive 
contexts, including violence (Held 2010). Findings of guilt, without question, need justice. Although 'justice' and 'care' moral reasoning are often juxtaposed, punishment can, and in my view, should, also involve the values and insights of caring practices.

Why Welfare and Punishment?

Punishment and social welfare are of joint interest. For many countries and systems of criminal law, many imprisoned offenders come from already heavily socially or economically disadvantaged backgrounds (van Eijk 2016; Carlen 2013, 91). ${ }^{1}$ Not all disadvantaged people become offenders. Yet, we are foolish to ignore this correlation even if we do not fully understand the cause (Reiman 2007, 29). As Carlen identifies, many imprisoned offenders are 'ill-equipped mentally, culturally, materially and socially for leading law-abiding lives' $(2013,92)$. Punishment frequently further undermines these capabilities.

\footnotetext{
1 UK Ministry of Justice longitudinal research suggest that, of Adult prisoners: $29 \%$ were abused as children (Williams, Papadopoulou, and Booth 2012, 9), 47\% have no qualifications (Hopkins 2012, 14), $25 \%$ suffer from both anxiety and depression (Cunniffe et al. 2012, 5), 25\% of women prisoners and $15 \%$ of men report symptoms of psychosis (Light, Grant, and Hopkins 2013, 20), and 46\% of women prisoners and $21 \%$ of men had previously attempted suicide (Light, Grant, and Hopkins 2013, 18). In the four weeks prior to custody, 64\% of prisoners report using illegal drugs (Light, Grant, and Hopkins 2013, 12), only 32\% were employed (Hopkins 2012, 7) and 15\% were homeless (Williams, Poyser, and Hopkins 2012, 1).
} 
There are some surprising similarities and differences between welfare and punishment policy. While welfare is generally considered to confer individual benefits; criminal punishment distinctively anticipates justifiable 'disbenefits'. Yet, we expect some supportive practices in punishment, for example mental health treatment, addiction support, and remedial education. Meanwhile, accessing state benefits requires individuals to demonstrate significant needs that they cannot meet. While we live in societies that prize apparent self-sufficiency and independence, rather than recognising relational interdependence and vulnerability as normal features of human lives, accessing state benefits may often be experienced as a humiliating process. Burdensome application processes exist partly to root out false claims, further stigmatising claimants as potential fraudsters (Wolff 1998).

Like welfare policy, punishment aims to provide a societal benefit, through interactions between individuals and state agents. Both practices can be understood more broadly than this individual level. Distinct from individuals, corporations can commit crimes (for example, in England \& Wales, Corporate Manslaughter, or offences under the Bribery Act 2010). Welfare policy may include state relationships with firms (for example, purchasing private-sector services for welfare administration and delivery). In these examples the state interacts with corporations, not individuals. 
However, my focus is on state-individual interactions in punishment and welfare, since this tells us about the ethical qualities of state-individual relationships.

There is a difference in scope between welfare policy and criminal punishment relating to citizenship and immigration status. State welfare eligibility is usually restricted by immigration status: only citizens, or those with certain permissions, are eligible for the full range of benefits. ${ }^{2}$ For example, one must satisfy an immigration status criterion and an age-related criterion to receive age-related benefits. Likewise, some offences can only be committed by people occupying relevant positions. Adults, in a position of trust with respect to a person under 18 (teachers, foster carers, social workers etc.), who intentionally touch their victim in a sexual manner, commit a specific offence under the Sexual Offences Act 2003. Persons occupying a position intended to safeguard another's financial interests (trustees or company directors) who abuse this position, acting dishonestly and intending financial gain, commit an offence variation under Section 4 of the Fraud Act 2006. While citizenship status may affect the applicability of offence types (for example, treason offences for citizens, immigration irregularities for non-citizens), the criminal law applies to all persons within the jurisdiction. While some applicable offences and punishments may vary,

\footnotetext{
2 Exceptions exist: In England \& Wales, Local Authorities have had a general duty regarding the welfare of all children in need within their area, under Section 17 of The Children Act 1989.
} 
liability to punishment does not change with citizenship status. If a defendant has mental capacity and either pleads or is found guilty at trial, then she is liable to punishment (Lewis 1976, 279).

While a 'doctrine of less eligibility' places offenders 'last in line' for any welfare good (Carlen 2013, 96); caring for offenders may amplify the effects of our caring. If we can enable offenders' own caring for themselves and others, this potentially extends the reach of our welfare resources across offenders, their dependents, and community. There are no guarantees that supported past offenders will successfully attempt social engagement in co-operative projects. Analogously, community engagement in programmes to address local social and economic needs can be similarly difficult to obtain: despite the efforts of local organisers, there is no guarantee that any local scepticism will be overcome (Barnes 2012, 137). Yet, without the work of local organisers, achieving such community engagement would be more difficult. Likewise, barriers to positive engagement with the community exist when a person struggles to meet her own needs and her dependents' needs. Barriers to social contribution are reduced when a person has help to meet their needs, and support in meeting their caring responsibilities.

Criminal justice responds to wrongs. Welfare policies respond to disadvantage, arising from differences in the distribution of opportunities or outcomes, and material 
wealth. Such questions of distribution are, at least in part, questions of social justice. Criminal justice processes cannot and should not be expected to single-handedly address distributive social injustices. But we can consider criminal punishment in light of broader social and political questions, about the distribution of responsibilities and resources for needs-meeting. Barnes argues that we should look not simply to alleviate disadvantage, but at how disadvantage is produced, and at more distant, formal and impersonal relationships $(2012,123,107)$. Criminal punishment may be an example of formal relationships which contribute to disadvantage production and entrenchment. I will discuss three ways in which supporting and caring for offenders provides opportunities to build capabilities rather than to compound disadvantage.

Care Ethics, Capabilities and Flourishing

Care ethics offers us two alternative perspectives for thinking about using state resources in the context of punishment and welfare. Firstly, a relational approach, acknowledging interdependence is highlighted in contemporary care ethics (Barnes $2012,65)$. Secondly, care ethics can be used to consider political decisions about distribution and social arrangements for meeting needs (Tronto 1993, 175; Robinson 1999, 30-33; Held 2015). Care ethics offers an approach to moral reasoning that values relationships, and recognises interdependence, vulnerability and dependence as 
normal features of human lives. Dependence varies between individuals and over our lives, and social conditions may conceal dependence. For much of history, caring work has been performed by slaves, poorly paid servants, and unpaid family members (Tronto 1993,113$)$. The privileged have been able to 'buy' their way out of caring labour, yet we all begin our lives in conditions of utter dependence. This has hidden the value of caring work.

Caring work, necessary for any form of human life (Held 2006, 17 cf; Herring $2013,68)$, meets essential needs for living well in our society which we cannot meet alone. Caring includes 'everything that we do to maintain, continue, and repair our "world" so that we can live in it as well as possible' to include 'our bodies, our selves, and our environment' woven together 'in a complex, life-sustaining web' (Fisher and Tronto 1991, 40). Core examples of 'capability-building' care work include the care and education of young children (learning the basic skills necessary to negotiate the social world); or medical care (a stroke survivor re-learning to walk). Caring work meets basic human needs, strengthens an individual's basic capabilities, and avoids unwanted and unnecessary harms (Engster 2007, 76). Good caring practices are attentive, responsive and respectful towards the individual receiving care (Engster 2007, 31), and engage with the care-receiver. 
Capabilities foster the skills we need to meet our own needs, our responsibilities, and to live flourishing lives. Some authors list basic capabilities (Nussbaum 2000, 78-80 employed by Engster, 2007), others champion the benefits of the concept, while remaining sceptical of the usefulness of lists (Sen 2004). Tronto suggests that Nussbaum and Sen's capability approach (1993) may open vital discursive space about human needs (Tronto 1993, 140, 2013, 162). Caring as 'capability-building' may help to build the mental, social and cultural capabilities, which Carlen identifies as low or lacking for many prisoners, capabilities that are further damaged by imprisonment $(2013,92)$.

Instrumentally necessary and intrinsically valuable social relationships require companionship and social connection, as well as individual capabilities and resources. For example: we cannot enjoy membership of an extended family, political participation, or socio-economic co-operation, such as employment, without others (Brownlee 2016, 66). Further, some individually enjoyed goods depend on prior collective action, such as individually benefitting through friendly societies or state welfare, or making individual use of public transport.

Why should we care? 
An inclusive, relational account of equality is offered by Eva Kittay motivating us towards equal recognition, inclusion and empathy for the other. 'We have each experienced care in our lives - even the most destitute among us - for without it, we cannot reach maturity' (Kittay 2005, 113, see also; Held 2006, 81). Everyone surviving beyond infancy has necessarily received care and therefore counts as 'some mother's child'. This account, Kittay suggests, is cross-cultural: based on our common human vulnerability and the mother-child relationship that, she argues, is found in all societies. Kittay intends to include any care provided by anyone, regardless of the relationship between care-giving 'mother' and vulnerable 'child'. Having been, at least once, the object of another's care, is fundamental to human dignity for Kittay (2005, 116).

We are entitled, Kittay writes, firstly to relationships within which we can receive care; and secondly to social support in our caring for others. This follows not from our rights (or needs) as independent individuals, but rather stems from connections with 'those with whom we have had and are likely to have relations of care and dependency' (Kittay 1999, 66). Kittay's indirect reciprocity, or 'nested' relationships are important for thinking about caring beyond dyadic relationships (Kittay 1999, 68). Others care for us, we care for different others. We either support a third group in their caring, or receive their support for our own caring, at different 
times. For example: I receive support from my family, enabling me to be fit to work with my students, facilitating their learning. My students and I in turn rely on the labour of university administrators, cleaners, and maintenance staff, to provide a suitable safe space for learning to take place.

Since human infants perish without nurturing support, we are all 'some mother's child': someone 'mothered' us, providing essential care, permitting our survival into the present (Kittay 2005, 114). As a mother's child, we each have the dignity of being a person in whom care has been invested, motivating empathy and inclusion, and Kittay's entitlement to care and support in care-giving. Yet, it is not helpful to conceive of caring as discrete, isolated, unidirectional acts. In many cases, care-giver and care-receiver experience directly reciprocated caring (Herring 2013, 153).

The strengths and weaknesses of the 'some mother's child' paradigm The 'some mother's child' paradigm prompts us towards empathy for the other and recognition of shared vulnerabilities. Recognising indirect reciprocity and nested dependencies is Kittay's key insight. Yet the rhetorical strength of the mother-child dyad risks overshadowing the nested relationships, indirect reciprocity and broader interdependence; and the language risks essentialising gender and infantilising us all in the moment of receiving care. With Barnes, it is inadequate to conceptualise care only 
in terms of the mother-child dyad, or any other single type of caring (Barnes 2015). A critical ethic of care requires us to recognise our responsibility for more (morally) distant and formal relationships $(2012,124)$, including state agent - individual relationships. Barnes argues that a strength of the feminist perspective is the recognition that care is not and cannot be contained within intimate, private, family relationships, since these exist within social relations of inequality (59). Kittay's wider and more recent work on this motivates us towards recognising the interdependencies and responsibilities in these wider relationships (Calder et al. 2016).

Mere survival does not include developing capabilities and flourishing, potentially setting the bar too low to identify care. Some children suffer unsupportive, abusive home lives, falling through child protection safety nets, and yet receive minimally sufficient nutrition and shelter to reach adulthood. Suppose a guardian provides minimal necessities for survival, but only to prevent a child from crying out in hunger or pain, rather than any concern for the child's wellbeing. It is important to be able to include those who survive, despite the poor care they receive, within broader social relationships, valuing them as interdependent individuals. Kittay's approach 
enables us to include childhood trauma survivors. Significant numbers of offenders are such survivors. $^{3}$

If the 'some mother's child' paradigm requires only survival of infancy, then criminal offenders, necessarily over the age of criminal responsibility (in England and Wales, a controversially low 10 years of age), are included. It is important that even 'incorrigible' offenders are included, if our status as 'some mother's child' grounds Kittay's 'distinctly human dignity' $(2005,116)$ as Kittay argues. Not all persons are liable to punishment (for example, persons lacking mental capacity, or children below the age of criminal responsibility), but all punished individuals are persons: offending does not change our personhood. Kittay's approach offers comprehensive inclusion for dignified treatment and entitlements to care.

The extent of treatment as 'some mother's child'

We can recognise the salience and centrality of relationships to human life without fetishising any particular relationship. Sometimes, the most caring act might be to end a relationship, or at least to suspend it for a time. No one is obliged to preserve a relationship with an abuser. If survivor and abuser are both willing, then healing and

\footnotetext{
${ }^{3}$ UK Ministry of Justice figures suggest that, of Adult prisoners, as children $24 \%$ had been taken into care (Williams, Papadopoulou, and Booth 2012, 8), 29\% had been abused, and $41 \%$ had observed violence in the home $(2012,9)$.
} 
repairing the relationship might be possible and preferable. But this will not always happen. Abusers are not entitled to care or support from, or a relationship with, their victim. But Kittay argues that even abusers are entitled to some care and relationships, which may include state social support.

'Entitlement' to a 'relationship' merges the language of care and relational ethics with the language of justice and rights. This allows us to include unchosen relationships, such as family relationships, and relationships between individuals and front-line state agents. We cannot choose our place of birth or parents. The state cannot choose who is born a citizen, or who enters its jurisdiction illegally. ${ }^{4}$ Universality is a core principle of international human rights law and a broadly, if not universally, accepted normative principle. Human rights may be argued to exist regardless of whether a particular state's law, practices or dominant moral paradigm explicitly acknowledge them (Nickel 2014). Human rights place duties on states with respect to persons by virtue of their humanity, and regardless of an individual's right to be within the territory (OHCHR 2017). Held argues that, alongside caring, rights to equal treatment are important. However, rights must be supported by cultural changes which accept the equal standing of others, and include concern that others' rights are fulfilled $(2015,628)$. It matters how the state treats individuals, given the

\footnotetext{
${ }^{4}$ Lawful migrants and naturalised citizens are an interesting exception.
} 
power and authority of the state's actions and what this communicates to an individual and her community about her equal personhood. These interactions with front-line or street-level bureaucrats have an impact on our life chances (Lipsky 1980, 9).

State-individual relationships are distinct from personal relationships. The state ought to treat, and be seen to treat, all persons in ways commensurate with equal basic dignity. Individuals may choose to break off personal relationships, exercising freedom of association (see Brownlee 2015 for a discussion of responsibilities as limits to this freedom). Punishment is a relational practice: enforcing the criminal law requires the state to maintain an ongoing relationship with all punished individuals. Even fines, curfews and deportation require administrative interactions to deliver the punishment. It is simply not open to the state to break off relations with those it punishes in the same way individuals might break off personal relationships.

While state - individual relationships cannot be dissolved during punishment, actions and choices for which we are responsible can change the nature of our relationships and Kittay's entitlements. Criminal offending breaches trust expectations, often ignoring both the rights and needs of others. This formulation includes offences against specific others, apparently 'victimless' crimes (for example, drug possession offences), and regulatory offences (for example, safety regulations and paying taxes 
that provide public services), which are part of the social and political organisation of responsibilities to minimise harms. Offenders remain persons, but 'lose standing', or hierarchical social respect as esteem within the community, changing these relationships (Bennett 2008, 153).

Criminal offending 'strips' us of some rights, yet some non-derogable rights cannot be removed under any circumstances (Kittay 1999, 69). Kittay offers an analogy with basic rights (equal inclusion, basic needs for food, shelter, and medical care). Some rights, such as liberty, may be abridged in lawful punishment. Basic rights apply to everyone and cannot be ignored, even for the most 'vicious' prisoners $(1999,69)$. On the 'rights' side of her analogy, we can include human rights applying specifically to people who may be, or who are, offenders: the right to a fair trial, no punishment without law, and the right to protection from torture or inhuman or degrading treatment (United Nations 1948 Article 10, 11, and Article 5 respectively). Offenders always retain some non-derogable and residual rights, even if exactly what these residual rights entail is under-theorized and unclear in practice (See Genders and Player 2013 , 4). Kittay argues that, likewise, individuals retain 'worthiness for a certain amount of care and connection' $(1999,69)$.

Further, offender's 'full treatment' as 'some mother's child' 'may be justifiably overridden by other social needs', as a 'temporary' measure. But our status as a 
mother's child, 'can never be fully relinquished' $(1999,69)$. While offending may explain deprioritising offenders' needs to prioritize the needs of a more vulnerable party (Kittay 1999, 69; Coverdale 2014, 107-10), offending erases neither rights nor needs. Offending cannot justify either ignoring offenders' needs and dehumanising offenders as individuals-in-relation; or ignoring offenders' rights and dehumanising offenders as rights bearers.

Using welfare wisely

Carlen links welfare policies to moral reciprocity: the state 'is obligated to satisfy the minimum needs of its citizens', in return 'citizens are expected to obey the law' (2013, 97). While she frames this as a direct reciprocity, this may also be viewed as an indirect reciprocity: the state secures a basic minimum for individuals, and each individual does not offend against others. Yet, as Carlen identifies, many offenders come from heavily disadvantaged backgrounds, such that the state cannot be seen to have fully met obligations to protect citizens or to have met their basic needs. R A Duff agrees that without fair access to the benefits of the shared socio-political community, the authority of the state to call offenders to account, and the subsequent legitimacy of punishment, is undermined $(2007,161-62)$. 
Punishment may misrecognise offenders' needs as merely indications of future criminal risk (Carlen 2013, 97). For example, the self-harming behaviour of Canadian women prisoners was categorized in the same way as other-directed violence among men: as a non-compliant, risk-generative behaviour, rather than as evidencing support requirements (Hannah-Moffat 2006, 188). The pre-existing disadvantage of many offenders, and the subsequent misrecognition of their needs, makes it all the more pressing that care is actively included in punishment. Offenders' rights as 'some mother's child' may be temporarily abridged during punishment, but their rights and needs cannot be ignored. Offenders are entitled to our care, as equal persons, community members, and as a mother's child.

Amplifying care

Providing care can help to address offenders needs. But there are three potential ways in which caring resources might be amplified, to benefit third parties when we use welfare resources to support people who have offended. I identify these three cases, before developing each in turn in the sections below. Firstly, if caring is a learned behaviour, then caring for offenders potentially facilitates offenders' learning about care, benefitting offenders by providing them with care and by providing a learning opportunity to lay the foundations for future participation in caring. Secondly, while 
many punishment practices presently deplete offenders' capabilities for caring, supporting offenders strengthens their capabilities for self-care and care for others. Thirdly, supporting offenders facilitates socio-economic co-operation and the potential for intrinsically valuable relationships, contributing to offenders' desistance and to flourishing lives across their communities. Supporting offenders strengthens the possibility of instrumentally valuable community benefits, which may contribute to reducing the needs for welfare support elsewhere in the community. These points are developed in the three sections below, each reflecting a facet of the entitlements Kittay identifies: to receive care, to support in care-giving, and to support others in their caring.

Receiving care and learning to care. Nel Noddings argues that caring is a learned behaviour (2002). Moral psychologist Wendy Hollway notes we are not born able to give care, and develop the capacity, particularly within the family and the mother-child relationship. This involves difficulty and effort on the part of the learner, and the provision of support and continuity from the same carer. This allows most of us to have developed some capacity for care by adulthood (Hollway 2006, 42). Even young children make attempts to give care, and Hollway reports several examples: a toddler comforting a parent as they have been comforted; or calling out to reassure an infant 
sibling, as they have observed their parent to act $(2006,43,60)$. However, all we require as 'some mother's child' is sufficient nurturing to reach maturity. Mere survival does not necessarily include the stable, supportive environment, which the complex process of learning care requires.

Three possibilities may explain failure of learning to care. Firstly, abused or neglected individuals may not have received sufficient care, and cannot be understood as having had an adequate opportunity to learn. Secondly, individuals may have received enough care, but at a time when they were not both ready and able to learn. Thirdly, individuals may have received and understood care, but rejected the lesson. Similarly, Jean Hampton suggests that although punishment may present moral arguments for avoiding criminal behaviour, the offender decides whether to listen (1984, 232), leaving space for her agency and autonomy.

That previous opportunities to learn about care were absent, failed or rejected, does not preclude offenders from learning to care in the present. Carlen criticizes contemporary prison practices more broadly as effectively de-habilitative $(2013,98)$, depleting offenders' practical and emotional resources to care for themselves and others. Yet we expect some support in punishment, such as mental health treatment, addiction support, and remedial education. By building on these practices and recognising them as caring, we can normalise care-giving and care-receiving; and 
provide an opportunity to learn practical and social skills for self-care and care for others. Some prisoners may never have had these learning opportunities (Jablecki 2005, 32; Braithwaite 2002, 98). This offers potential habilitation (Jablecki 2005, 32), strength building (Ward 2010) or capability building. This echoes Kittay's entitlement to relationships through which we receive care.

Care giving responsibilities: enabling offenders' caring. Receiving and learning about care could contribute to past offenders' building the resources and capabilities to respond constructively to future problems. Current punishment practices often deplete personal resources upon which an individual might draw, to meet caring responsibilities towards others or themselves. If prisoners live in fear, expending emotional energy to survive a hostile, threatening, violent and unsafe prison environment (Straub, Liebling, and Arnold 2011, iii-v), this leaves fewer resources for caring of any kind.

If many punished individuals are already disadvantaged, then Carlen argues that punishment can further reduce resources for self-care, and further undermines offenders' capabilities for living law-abiding lives on release $(2013,92)$. On the other hand, some current punishment practices can strengthen offenders' capabilities for caring. Clear examples include treatment for addiction or mental health needs, 
education, or peer-support (noted below), and offers offenders opportunities to learn and to practice caring, by providing self-care and other-directed care.

If prisoners earn low wages, this restricts their capability to provide for their families on the outside. Imprisonment often reduces offenders' opportunity for employment, both during incarceration and on release. Between 2005-2008, the prison reform organisation, the Howard League, operated a graphic design workshop as a 'social enterprise', within an English prison. Commercial approaches were harnessed to provide social benefits: generating charitable funding for the Howard League; and demonstrating both that meaningful work in prison is possible, and may further contribute to reducing recidivism (Green 2008). The desistance paradigm frames non-recidivism as an individual offender's choice, and as a process most likely to succeed with social and structural support. Building a new identity as a nonoffender requires time, effort and acceptance by others. Supportive families, communities and state agents, who positively reinforce an offender's project to recast their identity as a non-offender are crucial to the success of desistance (McNeill et al. $2012,2)$. Recent work on desistance details the role that work can play: the routines and relationships developed through work enable past offenders to develop 'constructive' and 'respectable' identities as "workers", and to establish legitimate ways of making money (Weaver and McNeill 2015, 101). Enabling prisoners to build 
skills, routines and identities as workers in prison may contribute to desistance from offending on release.

Prisoner employees built skills, experienced standard working routines, and were paid fairly, reflecting market take home pay. Prisoners took some responsibility for the needs of their families by sending money home (Howard League for Penal Reform 2010, 5); and attempted to repair the harms arising from crime by choosing to make charitable donations towards services for victims and prisoners' families (Green $2008,17-18)$. Working for a salary may not be the work we usually wish to include as core 'caring' work, which Tronto contrasts with 'office work' $(1993,134)$. Tronto is rightly sceptical of the use of money to buy services, as a 'pass-out' from caring responsibility for the privileged $(2013,80-82)$. This allows the rich to indirectly 'care about', in Tronto's terms, by purchasing services and passing direct 'caring-for' responsibilities to others $(1993,106)$.

Yet, for prisoners, paying money enables remote participation in caring since direct care-giving for those outside the prison is not possible. Further, a general assumption that offenders should participate more directly in supporting crime victims is not appropriate. While encouraging offenders to repair the harm of their offence is desirable, indirect methods are more appropriate, since victims must never be obliged to maintain any relationship with offenders. Barnes identifies distance-care through 
telemedicine, and other technologies $(2012,120)$. One reading of prisoners' use of money is as a low-tech means of sharing responsibility for, and contributing remotely to, caring practiced outside the prison, given that prisoners cannot care-for directly. One example is fundraising from within prison. In June 2016, 32 prisoners from one prison in the North of England raised over $£ 1000$ for a youth charity, by running a half marathon within the prison (The Visitor 2016).

Prisoners also provide face to face care within the prison. Samaritans prison 'Listeners' are trained in the same way as Samaritans helpline volunteers. Listeners give face-to-face peer support to prisoners feeling distressed or suicidal (Samaritans 2013). Supporting offenders to facilitate their care-giving resonates with Kittay's entitlement to relationships which support our caring practice.

Prison schemes which help parents to maintain contact and relationships with their children can benefit prisoners who are parents, their children and the child's other caregivers. Falling between enabling offenders' caring and offenders' supporting the care-giving of others, some programmes bring adult family members into prisons in England and Wales to work alongside offenders, and aim 'to help prevent institutionalisation and re-offending' through 'providing the basic, social and life skills' to help prisoners reflect on and strengthen skills and capabilities necessary for being 'part of a family and a community' (Safe Ground 2016). A study of similar programmes 
in Norway for fathers in prison suggests that these programmes can lay a foundation for desistance, but that follow-up support is required to realise this potential (Hansen 2017). Where people who have offended are able to care for themselves and supported in meeting their caring responsibilities towards their dependents, this reduces the need for prisoners, and those for whom they have or share caring responsibilities, to rely on state welfare.

Social flourishing: enabling others' choices and caring. Where offenders are able to care for themselves and their dependents, and to work towards developing and strengthening their capabilities, this increases opportunities for constructive engagement with their community, such as through employment or volunteering. Some UK employers particularly look to recruit ex-offenders such as Timpson's the cobbler, and Richard Branson's Virgin Group (James 2016), valuing the skills that offenders may have, looking past the offence at the person in the round. Past offenders able to manage their needs and their dependents needs, perhaps with support, are better placed to be employment-ready. Their availability to engage in this way facilitates the choices of others, such as employers, who wish to hire or otherwise co-operate with these individuals. 
Social contributions can be valuable even if they seem small. Offering and receiving social connection, including friendship and companionship, overlaps with the practices of giving and receiving care. On Brownlee's account, all persons deserve opportunities to offer and to contribute social connection to others in their community as of right, grounded in a basic human need to both give and receive social association, which are important for our wellbeing. Social connection is a valuable, positive contribution, providing important social goods to offenders and others. Recognising offenders as social contributors with something valuable to offer is both important for an offender's wellbeing as an intrinsically valuable person, as well as beneficial for others in her community. Offenders' support to enable other's actions and choices echoes Kittay's entitlement of others to our support in their caring.

Defending offenders' inclusion as subjects of care An empirical case can be made for supportive practices in punishment. The desistance paradigm, noted above as an offender centred process, resonates with care practices: valuing individualised, responsive support, valuing relationships, and recognising the role of the community in supporting desistance after punishment (Deering and Smith $2016,299)$. The importance of supportive social structures and relationships suggests that punishment practitioners can play a role in supporting offender-led desistance 
(Maruna and Toch 2001; McNeill, Raynor, and Trotter 2010; McNeill et al. 2012, 7). For instance, we know stable homes and jobs are important for reducing reoffending (May, Sharma, and Stewart 2008, 6). Desistance is less well-researched for minority groups, such as women offenders (Hedderman, Gunby, and Shelton 2011, 16); although the meta-analysis of Rodermond et al (2015) identifies factors requiring further research in relation to women offenders, such as the influence of parenthood, the criminality of peers, and employment.

Recent research suggests that the social connectedness and feelings of selfworth of formerly imprisoned US women was enhanced when they were permitted to support other desisting offenders. Acting as role models and mentors for more recently released prisoners, the women drew on shared experiences to help their mentees avoid mistakes. These care-giving mentors supported their mentee's desistance, while simultaneously improving their own community reintegration, and planning careers to give back to the community (Heidemann et al. 2016, 9, 22). This suggests that permitting offenders opportunities to practice self-care, care giving and community giveback, facilitated offenders' own community reintegration, in turn making engagement with others and broader social flourishing possible. Heidemann et al suggest this practice may offer some success in reducing recidivism. 
These empirical findings suggest that caring for offenders may amplify state resources, providing further benefits to others in the community beyond the supported offender. Welfare resources used to support offenders may be amplified in three ways, each of which resonate with Kittay's entitlements to relationships of care. Offenders may receive and learn about care, laying foundations for offenders' care-giving. Supported offenders are enabled to care for themselves and for their dependents, and offenders are able to contribute to their community by engaging with and supporting others (for example, mentees or employers), providing benefits to the wider community.

The amplification of state resources, and the benefits to others are welcome side-consequences. We cannot guarantee that supported offenders will choose and successfully achieve positive social contribution. But when we support offenders, we build capabilities for, and reduce the barriers to, offenders' engagement with and support for others. It is far easier to engage constructively in the broader life of one's community, working, volunteering, or simply being a good neighbour, with Kittay's entitlements to care. Primarily, we ought to care for offenders and support offenders' caring as part of punishment, in recognition of offender's equal personhood and entitlement to Kittay's relationships of care, as equal subjects of care and as care-givers. 


\section{Conclusion}

When prisoners are not able to care for themselves, or their families, the state pays punishment and welfare costs. When offenders receive care, and are enabled to build capabilities for caring, this potentially reduces the need for state welfare support. When offenders' lives are stable, and their caring responsibilities manageable, we remove barriers to broader engagement in social co-operation, to 'maintain, continue, and repair our 'world' so that we can live in it as well as possible' (Fisher and Tronto 1991, 40). Valuing offenders as 'some mother's child' recognizes their status as an intrinsically valuable person, an equal subject of care. Supporting offenders is a good use of finite state resources, since this builds capabilities for self-care and other directed care. A person's criminal offending might justify temporarily deprioritising their needs. Yet, even if rights are abridged following criminal conduct, this does not erase offenders' entitlement to some care and support.

Prisons should be places of care. Offenders are entitled to our caring as 'some mother's child', and should be valued primarily as persons in context, with families and futures; and not merely as 'assets' to be 'harnessed' and exploited. There is, however, potential for further instrumental community benefits from the amplification of welfare resources when this process enables offenders to give care and support to others, in 
addition to recognising offenders as intrinsically valuable people, entitled to support as 'some mother's child'.

\section{Acknowledgements}

The first draft of this paper was presented at The Ethics and Social Welfare $10^{\text {th }}$ Anniversary Conference. I am grateful to conference participants for their valuable insights, to Diego de Merich for his feedback on an early draft, and to two anonymous reviewers for their generous and helpful comments.

Disclosure statement

No potential conflict of interest was reported by the author.

Author

Helen Brown Coverdale teaches at the London School of Economics. Her research in applied legal and political theory focus on equality and the moral qualities of interactions between the state and individuals. She holds an AHRC funded PhD (LSE), an MA (UCL) and BA (Manchester), and previously worked in the criminal justice sector, and as a parliamentary researcher. 
References

Barnes, Marian. 2012. Care in Everyday Life : An Ethic of Care in Practice. Bristol: Policy. - - - 2015. 'Beyond the Dyad: Exploring the Mutlidimensionality of Care'. In Ethics of Care: Critical Advances in International Perspective, edited by Marian Barnes, Tula Brannelly, and Marian Barnes. Policy Press.

Barnes, Marian, and David Prior. 2009. Subversive Citizens: Power, Agency and Resistance in Public Services / Edited by Marian Barnes and David Prior. Bristol: Policy.

Bennett, Christopher. 2008. The Apology Ritual a Philosophical Theory of Punishment. Cambridge: Cambridge University Press.

Braithwaite, John. 2002. Restorative Justice and Responsive Regulation. Studies in Crime and Public Policy. Oxford: Oxford University Press.

Brownlee, Kimberley. 2015. 'Freedom of Association: It's Not What You Think'. Oxford Journal of Legal Studies 35 (2): 267-82. doi:10.1093/ojls/gqu018.

- - 2016. 'Ethical Dilemmas of Sociability'. Utilitas 28 (1): 54-72. doi:10.1017/S0953820815000175.

Calder, Gideon, Sarah Banks, Marian Barnes, Beverley Burke, Lee-Ann Fenge, Liz Lloyd, Mark Smith, Steve Smith, Nicki Ward, and Derek Clifford. 2016. 'Conference Report: ?Ethics and Social Welfare in Hard Times?, London, 1?2 September 2016'. Ethics and Social Welfare 10 (4): 361-66. doi:10.1080/17496535.2016.1239603.

Cameron, David. 2016. 'Prison Reform: Prime Minister's Speech'. February 8. https://www.gov.uk/government/speeches/prison-reform-prime-ministersspeech.

Carlen, Pat. 2013. 'Against Rehabilitation; for Reparative Justice'. In Crime, Justice and Social Democracy: International Perspectives, edited by Kerry Carrington, 89104. Basingstoke : Palgrave Macmillan,.

Coverdale, Helen Brown. 2014. 'Punishing with Care: Treating Offenders as Equal Persons in Criminal Punishment'. London: Department of Law, London School of Economics \& Political Science.

Cunniffe, Charles, Rik Van de Kerckhove, Kim Williams, and Kathryn Hopkins. 2012. 'Estimating the Prevalence of Disability amongst Prisoners: Results from the Surveying Prisoner Crime Reduction (SPCR) Survey'. Research Summary. Research Summary. London: Ministry of Justice. https://www.gov.uk/government/uploads/system/uploads/attachment_data/fi le/278827/estimating-prevalence-disability-amongst-prisoners.pdf. 
Deering, John, and Steven R. Smith. 2016. 'Revising Wolff's Support for Retribution in Theories of Punishment: Desistance, Rehabilitation, and Accommodating Individual and Social Accounts of Responsibility'. Ethics and Social Welfare 10 (4): 289-303. doi:10.1080/17496535.2016.1183032.

Duff, R. A. 2007. Answering for Crime: Responsibility and Liability in Criminal Law. Oxford: Hart Pub.

Eijk, G. van. 2016. 'Socioeconomic Marginality in Sentencing: The Built-in Bias in Risk Assessment Tools and the Reproduction of Social Inequality'. Punishment \& Society, September. doi:10.1177/1462474516666282.

Engster, Daniel. 2007. The Heart of Justice: Care Ethics and Political Theory. Oxford: Oxford University Press.

Fisher, Berenice, and Joan C Tronto. 1991. 'Towards a Feminist Theory of Care'. In Circles of Care: Work and Identity in Women's Lives, edited by Emily K. Abel and Margaret K. Nelson, 35-64. Albany, N.Y.: State University of New York Press.

Genders, Elaine, and Elaine Player. 2013. 'Rehabilitation, Risk Management and Prisoners' Rights'. Online First Criminology and Criminal Justice, no. forthcoming: 1748895813502500. doi:10.1177/1748895813502500.

Green, Penny. 2008. 'Prison Work and Social Enterprise: The Story of Barbed'. London: Howard League for Penal Reform.

Hampton, Jean. 1984. 'The Moral Education Theory of Punishment'. Philosophy and Public Affairs 13 (3): 208-38.

Hannah-Moffat, Kelly. 2006. 'Pandora's Box: Risk/Need and Gender-Responsive Corrections'. Criminology \& Public Policy 5 (1): 183-192. doi:10.1111/j.17459133.2006.00113.x.

Hansen, Gunnar Vold. 2017. "Fathers in Prison" Program May Create a Basis for Desistance among Norwegian Prisoners'. Journal of Offender Rehabilitation 56 (3): 173-87. doi:10.1080/10509674.2017.1290008.

Hedderman, Carol, Clare Gunby, and Nicola Shelton. 2011. 'What Women Want: The Importance of Qualitative Approaches in Evaluating Work with Women Offenders'. Criminology and Criminal Justice 11 (1): 3-19. doi:10.1177/1748895810392188.

Heidemann, G., J. A. Cederbaum, S. Martinez, and T. P. LeBel. 2016. 'Wounded Healers: How Formerly Incarcerated Women Help Themselves by Helping Others'. Punishment \& Society 18 (1): 3-26. doi:10.1177/1462474515623101.

Held, Virginia. 2006. The Ethics of Care: Personal, Political, and Global. Oxford; New York: Oxford University Press.

- - - 2010. 'Can the Ethics of Care Handle Violence?' Ethics and Social Welfare 4 (2): 115-29. doi:10.1080/17496535.2010.484256. 
- - . 2015. 'Care and Human Rights'. In Philosophical Foundations of Human Rights., edited by Rowan Cruft, Matthew Liao, and Massimo Renzo, 624-41.

Herring, Jonathan. 2013. Caring and the Law. Oxford: Hart Pub.

Hinsliff, Gaby. 2006. 'Cameron Softens Crime Image in "Hug a Hoodie" Call'. The Guardian, July 9, sec. Politics. http://www.theguardian.com/politics/2006/jul/09/conservatives.ukcrime.

Hollway, Wendy. 2006. The Capacity to Care: Gender and Ethical Subjectivity. London ; New York: Routledge.

Hopkins, Kathryn. 2012. 'The Pre-Custody Employment, Training and Education Status of Newly Sentenced Prisoners'. Results from the Surveying Prisoner Crime Reduction (SPCR) Longitudinal Cohort Study of Prisoners. Ministry of Justice Analytical Services, Ministry of Justice Research Series. London: Ministry of Justice. https://lemosandcrane.co.uk/resources/pre-custody-empl-trainingedu-status-newly-sentenced-prisoners.pdf.

Howard League for Penal Reform. 2010. 'Barbed: What Happened Next'. London: Howard League for Penal Reform. http://howardleague.org/wpcontent/uploads/2016/05/Barbed_what_happened_next_web.pdf.

Jablecki, Lawrence. 2005. 'Changing the Lives of Prisoners: A New Agenda.' The Humanist.

James, Erwin. 2016. 'Virgin Trains Helps Ex-Offenders to Put Their Lives Back on Track'. The Guardian, July 20, sec. Society. https://www.theguardian.com/society/2016/jul/20/rail-company-helps-exoffenders-virgin-trains.

Kittay, Eva Feder. 1999. Love's Labor: Essays on Women, Equality, and Dependency. Thinking Gender. New York: Routledge.

- - . 2005. 'Equality, Dignity, and Disability'. In Perspectives on Equality: The Second Seamus Heaney Lectures, edited by Mary Ann Lyons and Fionnuala Waldron, 93119. Dublin: The Liffey Press.

Lewis, J. R. 1976. Civil and Criminal Procedure. 2nd ed. North Shields: North Shields.

Light, Miriam, Eli Grant, and Kathryn Hopkins. 2013. 'Gender Differences in Substance Misuse and Mental Health amongst Prisoners'. Results from the Surveying Prisoner Crime Reduction (SPCR) longitudinal cohort study of prisoners. London: Ministry of Justice. Ministry of Justice Analytical Series. 2013. http://www.antoniocasella.eu/archipsy/Light_2013.pdf.

Lipsky, Michael. 1980. Street Level Bureaucracy: Dilemmas of the Individual in Public Services. New York: Russell Sage. 
Maruna, Shadd, and Hans Toch. 2001. Making Good: How Ex-Convicts Reform and Rebuild Their Lives. 1st ed. Washington, D.C.: American Psychological Association.

May, Chris, Nalini Sharma, and Duncan Stewart. 2008. 'Factors Linked to Reoffending'. Ministry of Justice, Communications Directorate. http://webarchive.nationalarchives.gov.uk/+/http://www.justice.gov.uk/public ations/research2008.htm.

McNeill, Fergus, Stephen Farrall, Claire Lightowler, and Shadd Maruna. 2012. 'How and Why People Stop Offending: Discovering Desistance'. 15. Discovering Desistance, Funded by the Economic \& Social Research Council. Glasgow: Institute for research and innovation in social services.

McNeill, Fergus, Peter Raynor, and Chris Trotter, eds. 2010. Offender Supervision: New Directions in Theory, Research and Practice. Oxon: Willan Publishing. http://www.routledge.com/books/details/9781843929352/.

Ministry of Justice. 2016. 'Safety and Prison Reform'. White Paper Cm 9350. London: Ministry of Justice. https://www.gov.uk/government/uploads/system/uploads/attachment_data/fi le/565014/cm-9350-prison-safety-and-reform-_web_.pdf.

Nickel, James. 2014. 'Human Rights'. In The Stanford Encyclopedia of Philosophy, edited by Edward N. Zalta, Winter 2014. http://plato.stanford.edu/archives/win2014/entries/rights-human/.

Noddings, Nel. 2002. Starting at Home: Caring and Social Policy. London: University of California Press.

Nussbaum, Martha Craven. 2000. Women and Human Development: The Capabilities Approach. Cambridge: Cambridge University Press.

Nussbaum, Martha Craven, and Amartya Sen, eds. 1993. The Quality of Life. Oxford [England] ;New York: Clarendon Press ;Oxford University Press.

OHCHR. 2017. 'OHCHR | What Are Human Rights'. http://www.ohchr.org/EN/Issues/Pages/WhatareHumanRights.aspx.

Reiman, Jeffrey H. 2007. The Rich Get Richer and the Poor Get Prison: Ideology, Class, and Criminal Justice. 8th ed. Boston: Pearson.

Robinson, Fiona. 1999. Globalizing Care: Ethics, Feminist Theory, and International Relations. Feminist Theory and Politics. Boulder, Colo.: Westview Press.

Rodermond, Elanie, Candace Kruttschnitt, Anne-Marie Slotboom, and Catrien CJH Bijleveld. 2015. 'Female Desistance: A Review of the Literature'. European Journal of Criminology 13 (1): 3-28.

Safe Ground. 2016. 'Programmes \& Services'. Safe Ground. http://www.safeground.org.uk/programmes-services/. 
Samaritans. 2013. 'The Listener Scheme'. Samaritans. http://www.samaritans.org/yourcommunity/our-work-prisons/listener-scheme.

Sen, Amartya. 2004. 'Capabilities, Lists, and Public Reason: Continuing the Conversation'. Feminist Economics $10 \quad$ (3): $\quad$ 77-80. doi:10.1080/1354570042000315163.

Sim, Joe. 2016. 'Prison Safety and Reform: When? I Centre for Crime and Justice Studies'. December 2. https://www.crimeandjustice.org.uk/resources/prisonsafety-and-reform-when.

Straub, Christina, Alison Liebling, and Helen Arnold. 2011. 'An Exploration of StaffPrisoner Relationships at HMP Whitemoor: 12 Years On'. Cambridge: Cambridge institute of Criminology Prison Research Centre. http://mojbuild.squiz.co.uk/downloads/publications/research-and-analysis/mojresearch/staff-prisoner-relations-whitemoor.pdf.

The Visitor. 2016. 'Prisoners Do a Lap of Honour'. http://www.thevisitor.co.uk/news/local/prisoners-do-a-lap-of-honour-17944746.

Tronto, Joan C. 1993. Moral Boundaries: A Political Argument for an Ethic of Care. New York: Routledge.

Tronto, Joan C. 2013. Caring Democracy: Markets, Equality, and Justice. New York: New York University Press.

United Nations. 1948. 'Universal Declaration of Human Rights'. United Nations General Assembly.

Ward, Tony. 2010. 'The Good Lives Model of Offender Rehabilitation: Basic Assumptions, Aetiological Commitments and Practical Implications'. In Offender Supervision: New Directions in Theory, Research and Practice, edited by Fergus McNeill, Peter Raynor, and Chris Trotter, 41-64. Oxon: Willan Publishing.

Weaver, Beth, and Fergus McNeill. 2015. 'Lifelines Desistance, Social Relations, and Reciprocity'. Criminal Justice and Behavior 42 (1): 95-107.

Williams, Kim, Vea Papadopoulou, and Natalie Booth. 2012. 'Prisoners' Childhood and Family Backgrounds'. Results from the Surveying Prisoner Crime Reduction (SPCR) Longitudinal Cohort Study of Prisoners. Ministry of Justice Analytical Services, Ministry of Justice Research Series. London: Ministry of Justice. https://lemosandcrane.co.uk/resources/prisoners-childhood-familybackgrounds.pdf.

Williams, Kim, Jennifer Poyser, and Kathryn Hopkins. 2012. 'Accommodation, Homelessness and Reoffending of Prisoners: Results from the Surveying Prisoner Crime Reduction (SPCR) Survey'. Research Summary 3/12. Research Summary. London: Ministry of Justice. 
Wolff, Jonathan. 1998. 'Fairness, Respect, and the Egalitarian Ethos'. Philosophy and Public Affairs 27 (2): 97-122. 